Instructions for authors, subscriptions and further details:

\title{
http://rimcis.hipatiapress.com
}

\section{The Effect of Sustainable Development on Economics Complexity in OECD Countries}

Sevda Yaprakli ${ }^{1}$, Erdemalp Özden²

1) Atatürk University

2) Bayburt University

Date of publication: Online First 27 July 2021, Issue published 30 July 2021 Edition period: July 2021 - November 2021

To cite this article: Yaprakli, S., \& Özden, E. (2021). The Effect of Sustainable Development on Economics Complexity in OECD Countries. International and Multidisciplinary Journal of Social Sciences, 10(2), 51-80. doi: 10.17583/rimcis.7949

To link this article: http://doi.org/10.17583/rimcis.7949

\section{PLEASE SCROLL DOWN FOR ARTICLE}

The terms and conditions of use are related to the Open Journal System and to Creative Commons Attribution License(CC-BY). 


\section{The Effect of Sustainable Development on Economic Complexity in OECD Countries}

Sevda Yaprakli

Atatürk University
Erdemalp Özden

Bayburt University

\section{Abstract}

Economic complexity showing a holistic measure of countries' economic productive power and characteristics has become a new tool for understanding the dynamics of the economy. Examining the relationship between sustainable development and this new tool is vital in determining new policies. By applying panel data of OECD countries covering different development levels from 1996 to 2017 to a data-driven dynamic econometric model, the research provides fresh insight between sustainable development and economic complexity. The results indicate that economic complexity is significantly affected by sustainable developments' economic indicators such as GDP, FDI, R\&D expenditure, social indicators such as human development, income inequality, and environmental indicators such as productionbased $\mathrm{CO}_{2}$ emissions, renewable energy consumption, and greenhouse gas. The research, consequently, suggests that switching to technology and knowledge-based production processes, expanding qualified production factor capacity, raising social living standards, and making investments in the green economy will foster economic complexity while ensuring stable sustainability.

Keywords: economic complexity, sustainable development, system GMM, OECD countries 


\section{El efecto del desarrollo sostenible en la complejidad económica de los países de la OCDE}

Sevda Yaprakli

Atatürk University

\author{
Erdemalp Özden \\ Bayburt University
}

\section{Resumen}

La complejidad económica que muestra una medida holística del poder productivo económico y las características de los países se ha convertido en una nueva herramienta para comprender la dinámica de la economía. Examinar la relación entre el desarrollo sostenible y esta nueva herramienta es vital para determinar nuevas políticas. Al aplicar datos de panel de países de la OCDE que cubren diferentes niveles de desarrollo desde 1996 a 2017 a un modelo econométrico dinámico basado en datos, la investigación proporciona una nueva perspectiva entre el desarrollo sostenible y la complejidad económica. Los resultados indican que la complejidad económica se ve significativamente afectada por los indicadores económicos del desarrollo sostenible como el PIB, la IED, el gasto en I + D, los indicadores sociales como el desarrollo humano, la desigualdad de ingresos y los indicadores ambientales como las emisiones de $\mathrm{CO}_{2}$ basadas en la producción, el consumo de energía renovable y gases de efecto invernadero. En consecuencia, la investigación sugiere que el cambio a la tecnología y los procesos de producción basados en el conocimiento, la expansión de la capacidad de los factores de producción calificados, el aumento de los niveles de vida social y la realización de inversiones en la economía verde fomentarán la complejidad económica al tiempo que garantizan una sostenibilidad estable.

Palabras clave: complejidad económica, desarrollo sostenible, sistema GMM, países de la OCDE 
ince the industrial revolution, the agents of production of countries and $\circlearrowleft$ their effects on production, welfare, and ecological life cycle have shown rapid change and development. This situation has led to the gradual change in the traditional growth and development concepts, and the concept of sustainability comes into prominence. By virtue of sustainability, which can be defined as providing at least the present conditions without harming the world where future generations will live in terms of welfare, a development approach that can better adapt to new conditions has emerged (WCED, 1987).

According to this new understanding known as Sustainable Development (SD) in the economics literature, making the increase in material welfare sustainable depends on increasing social equality and reducing environmental and ecological problems. It is possible to say that these three fundamental pillars (economic, social, and environmental) of SD make it challenging to build a consensus on many topics such as definition, measurement, theoretical approach, and policy suggestions related to SD. This phenomenon, which enables the formation of different combinations between economic, social, and environmental depending on the situation, is addressed within its scope a new approach called "Sustainomics" (Munasinghe, 2001). According to the Sustainomics approach, the economic, social, and environmental aspects and sub-components of SD should be equilibrated, and this equilibrium should be maintained consistently. Thus, it becomes possible to increase financial prosperity with the manufacturing of products and services economically, achieve individual and social goals socially, and act together to create an environmentally sound and highly resilient ecosystem (Munasinghe, 2009).

On the other hand, in today's world, where a globalized-integrated economic system begins to exist, it is seen that the indicators of SD have direct and indirect impacts on many economic-commercial factors. In this context, one of the leading prominent elements is the concept of Economic Complexity (EC). In general, the EC is one of the new concepts that shows that a country's ability to achieve a comparative competitive advantage depends on its capacity to manufacture and export with high added-value and complex goods. EC, which entered the economics literature in the mid-2000s, is about diversifying countries' goods and transforming them into a more complex structure. It is one of the leading indicators that is significantly affected by the countries' economic performances and reveals countries' success levels in 
production and foreign trade (Hidalgo, 2009). EC covers the synthesis of production inputs such as infrastructure, natural resources, labor, capital, information, institutions, etc., in short, each country's production capacity. Production capacity shows the diversity, quality, and level of knowledge of the tradable goods produced domestically and can be subject to domestic and foreign demand that countries can produce (Balsalobre et al., 2019). It is not easy to comprehensively measure and analyze the production capacity, which includes many factors in all dimensions (Simoes \& Hidalgo, 2011). Therefore, the EC concept and the EC index are used as indicators of production capacity in the literature.

EC reflects the amount of technical knowledge in a country's total production capacity and its production structure accordingly (Hausmann et al., 2020). Economic Complexity Index (ECI) measures the diversity and ubiquity (the number of countries which could produce these goods and the technical knowledge or complexity of the goods) of competitive export goods (differentiated or similar goods that can be substituted for each other) produced according to a nation's production capacity (Hausmann et al., 2020; Hidalgo \& Hausmann, 2009). EC shows to what extent the income levels of economies and the goods they produce are different from others and indicates which countries are more specialized in producing which goods than others (Balsalobre et al., 2019; Hartmann, 2014; Hausmann et al., 2020). Hence, for example, a small number of Developed Countries with similar factor endowments and concentration have the capacity/knowledge to produce and export competing goods such as a microchip, computer, vehicle, etc.; in a word, these countries have similar EC levels (Hausmann et al., 2020; Hidalgo, 2009). In a nutshell, the products of countries with high EC levels are more complex, less in number, and these countries generally have monopoly power. In this respect, it can be said that countries with high EC levels can provide high gains, especially in intra-industry trade.

EC, which offers the opportunity to examine countries according to their production capacities, is affected by SD, which is essential in alleviating the development differences between countries. It is observed that countries with high SD levels have a higher potential to produce in line with their production capacities and to increase the complexity of exportable goods. In this respect, the SD-EC relationship has brought a different perspective to development. Countries with relatively higher growth and development rate may have more 
complex production structures. The complexity level of merchandise products produced by the countries can be shaped according to the countries' development levels (Felipe et al., 2012; Hausmann \& Klinger, 2007; Ourens, 2017). Accordingly, from the 1990s, when the use of information and communication technologies started to increase, manufacturing and exporting of technological, complex, and differentiated commercial goods, which are export of goods with high EC level, increased with the advance in the economic development level, especially in developed countries. The situation has caused the SD levels of the countries to be closely linked with the EC.

Based on the economic development and importance of SD in the EC process, this study tries to determine whether $\mathrm{SD}$, which is addressed with its extent, such as economic, social, and environmental transformation in OECD countries, can affect EC. To comprehend this effect, we employed econometric methods and made policy recommendations for increasing the EC level. For this purpose, we first gave general explanations about SD and EC and then examined domestic and foreign applied studies on the subject. Finally, we introduced the data and method used in the application and evaluated the findings by giving the analysis results.

\section{The Effects of Sustainable Development on Economic Complexity}

Since the 1990s, when the international expansion of the commercial and financial process accelerated, many countries started to make changes in commodity production composition and content, considering the consumer demands. The increase in the foreign trade volume of bio-high technology and knowledge-intensive competitive goods and improved trade terms were effective in this change. This change and development, which allows countries to specialize in some complex commodity groups and produce large-scale production that creates positive externalities, has reached higher rates in countries with high economic growth-development rates (Spatafora et al., 2012). Based on the respective alteration and development process, it is possible to list the main effects of SD on EC as follows.

The transformation process that emerged with SD and the increase in income level is vital in terms of adaptation to international competition and changes in demand conditions, producing large-scale production for the future, transition to different capacities, and more complex production 
processes. Countries that can change their production structures created according to current production capacities in harmony with new developments and production processes are more likely to make efficient and productive investments (Ourens, 2017).

The potential of developed countries with high income to produce and export goods with superior technical knowledge (high level of Product Complexity (PC)) such as space technology, medical drugs, mobile phones, and tablets is relatively higher. This is because the production of goods with high PC level includes factors that require high financial resources such as conducting R\&D studies together with companies, making large-scale production, human capital with high expertise, technical production capability, governance quality, etc. (Hausmann \& Klinger, 2007; Spatafora et al., 2012).

While high-tech (complex) goods are primarily exported in developed countries with high income and high SD levels, raw materials and laborintensive (primary) goods are exported in low-income countries. Considering this situation, as the nation's level of income and development standard increase, the goods' content subject to export changes, and the quality and value appreciate (Hausmann et al., 2006).

With the development process of the Developing Countries, improving their production capacities and accessing new production techniques can enable them to shift from complementary commercial goods (interindustry trade) to differentiated goods (vertical intra-industry trade) with competitive characteristics and to export advanced (complex) technology goods (Jarreau \& Poncet, 2012; Rodrik, 2006).

Thanks to the economic development of countries, the enhancement in the quality of technological knowledge, the nature of human capital, the success of public policies implementation, the effectiveness of R\&D activities, and the success of the governance network and sharing can contribute to the increase of export complexity of countries (Hausmann et al., 2006).

On the other hand, the expenditures made (resource cost) to prevent the production and other economic activities carried out within the scope of SD from harming the environment and using environmental resources more effectively (like producing environmentally friendly goods) have increased. This situation may increase retail product prices and decrease competitiveness in foreign trade (Cosbey, 1996). 
With the increase in the SD level, there may be an increase in foreign direct investments entering the country. In this way, local companies can produce goods (with a high PC) that increase the EC level by using advanced technology production techniques and increase the share of these goods in total exports (Jarreau \& Poncet, 2012). However, suppose most local companies that cannot cope with foreign companies' competition are in the majority. In that case, the technological capacity gap between local and foreign companies may increase, and local companies' export earnings and market shares may decrease.

In countries with a low level of development and weak global competitive advantage, the capacity to produce high technology goods (production structure) and countries' EC levels may be lower (Hausmann et al., 2020). Factors such as non-dynamic domestic market conditions, unproductive investments, a low level of technological knowledge, and economic structural rigidity may adversely affect the EC's level (Jarreau \& Poncet, 2012).

In countries with innovative, knowledge-intensive, and flexible sectoral infrastructure, it may be easier to produce differentiated goods with high technology content. While economic development is sustainably supported by structural changes that center innovation, the level of awareness develops based on the company and society. The living standards and ability levels of people living in countries with good infrastructure are higher than those without this infrastructure. For example, goods that are produced in city centers are often technology-intensive, requiring more proficient knowledge, information networks, and training.

Countries with high-income levels, dealing with growth, poverty, and other social problems, and producing under economic capacity can be achieved at lower costs. Progress in social areas such as education, health, access to technology can enable individuals involved in the production process to develop capacities suitable for new fields of activity, to produce higher quality goods, and to be employed in areas where they are efficient and productive. In this way, it is possible to produce goods and services with high technology content and complexity based on R\&D with cost reductions (with economies of scale) (Hartmann, 2014).

In the context of the fundamental effects listed above, SD is meaningful as long as it supports the countries' EC level and increases the gains from their foreign trade. It is possible to say that for the net effect of SD on EC to be 
positive, it is necessary to take to stable and sustainable policy measures to ensure a balance between advantages and disadvantages.

\section{Literature Review}

Since the 2000s, most of the studies conducted to figure out the outcomes of the economic, social, and environmental indicators of SD on EC have focused on each determinant's effectiveness rather than all SD indicators. It is possible to summarize the limited number of studies dealing with SD and EC's relationship in terms of their results.

Key studies that analyze the impact of SD's economic indicators, for instance, GDP, employment, trade openness, etc., on EC can be listed as follows; Balsalobre et al. (2019), Bastos \& Wang (2015), Britto et al. (2017), Can \& Gozgor (2016), Cristelli et al. (2015), Demiral (2016), Ferrarini \& Scaramozzino (2013), Ferraz et al. (2017), Fortunato et al. (2015), Hausmann et al. (2020), Jarreau \& Poncet (2012), Mealy et al. (2019), Özgüzer \& Binatlı (2016), Poncet \& de Waldemar (2013), Stojkoski \& Kocarev (2017) and Yalta $\&$ Yalta (2021). In these studies, it has been determined that the economic indicators of SD are generally related to the EC level and that the relationship is positive at a certain (threshold) level of development.

On the other hand, Demiral (2016), O’Clery (2016), and Özgüzer \& Binatlı (2016) stated in their studies that the relationship between SD and EC level is negative. In addition, Stojkoski \& Kocarev (2017) and Yalta \& Yalta (2021) indicated no relationship between GDP and EC, one of the leading economic indicators of SD. In these studies, it has been determined that EC is one of the most fundamental concepts explaining income differences between countries. Also, in these studies, it was determined that countries with low development levels have low EC levels. It was emphasized that the economic development level and economic and product complexity increased with the improvement in SD's economic indicators, in general, considering all the studies. Besides, it was also noted that the economic structure has changed towards competitive advantage.

In the critical studies, such as Ferrarini \& Scaramozzino (2013), Ferraz et al. (2017), Hartmann et al. (2017), Hausmann et al. (2020), and Yalta \& Yalta (2021), examining the effect of social indicators of SD on EC assert that the increase in the economic development level increases the positive connection 
between EC and social indicators, and the EC level has increased in socially developed countries. In the meantime, with the studies conducted by Hartmann et al. (2016) and Hartmann et al. (2017), it has been revealed that negative social indicators such as income inequality, low human capital level, institutional inadequacy, etc., have adverse effects on EC. According to these studies, SD, which is not socially sufficient, causes a decrease in countries' competitive advantage and a low EC level.

According to the growth and development literature, the relationship between SD and EC's environmental determinants is bilateral. The first is that the improvement in environmental indicators allows for quality/price differentiation in export-oriented production and increased the goods/sector's complexity. Therefore, it increases the income and foreign trade earnings of investors. Second, increasing the EC level encourages green and renewable energy-based development. Thus, there is a relationship between EC and SD shaped by the countries' economic development levels (Hartmann, 2014). In the studies conducted on this subject, such as Can \& Gozgor (2016), Mealy \& Teytelboym (2018), Neagu \& Teodoru (2019), and Yilanci \& Pata (2020), it has been concluded that there is an improvement in the environmental indicators (greenhouse gas emission, renewable energy consumption, waste, etc.) of the countries with high economic development and high EC levels. Neagu \& Teodoru (2019), Romero \& Gramkow (2020), and Swart \& Brinkmann (2019) determined that the level of EC is low in countries where environmental indicators are unwell.

Leading applied studies conducted in different years for 2012-2020 can be summarized as in Table 1.

Table 1.

Literature Summary of the Relationship Between EC and SD

\begin{tabular}{|c|c|c|c|c|c|}
\hline $\begin{array}{l}\text { Author(s) / } \\
\text { Year }\end{array}$ & Countries & $\begin{array}{l}\text { Time } \\
\text { Periods } \\
\end{array}$ & Indicator(s) & Method(s) & Result(s) \\
\hline $\begin{array}{l}\text { (Jarreau \& } \\
\text { Poncet, 2012) }\end{array}$ & $\begin{array}{l}30 \\
\text { Regions } \\
\text { in China }\end{array}$ & $\begin{array}{l}1997- \\
2007\end{array}$ & $\begin{array}{l}\text { Economic } \\
\text { performance and } \\
\text { growth }\end{array}$ & $\begin{array}{l}\text { Panel Data } \\
\text { Analysis }\end{array}$ & $\begin{array}{l}\text { Regions with } \\
\text { high EC have } \\
\text { a higher } \\
\text { growth rate. }\end{array}$ \\
\hline $\begin{array}{l}\text { (Poncet \& de } \\
\text { Waldemar, } \\
\text { 2013) }\end{array}$ & $\begin{array}{l}22 \\
\text { Provinces } \\
\text { in China }\end{array}$ & $\begin{array}{l}1997- \\
2008\end{array}$ & $\begin{array}{l}\text { The income per } \\
\text { capita, Human }\end{array}$ & $\begin{array}{l}\text { Panel Data } \\
\text { Analysis }\end{array}$ & $\begin{array}{l}\text { EC is higher } \\
\text { in } \\
\text { economically }\end{array}$ \\
\hline
\end{tabular}




$\begin{array}{llll} & & \begin{array}{l}\text { capital, Trade } \\ \text { Openness, FDI }\end{array} \\ \text { (Ferrarini \& } 89 & 1990- & \begin{array}{l}\text { GDP, human } \\ \text { capital, year of Cross- } \\ \text { education, labor Sectional } \\ \text { force } \\ \text { participation rate } \\ \text { 2013) }\end{array} \text { Countries 2009lysis }\end{array}$

GDP,

1960- institutional

(Hausmann et All

al., 2014) quality, human capital, competitiveness
(Bastos \& 103 Wang, 2015) Countries

1970 2010
GDP, commodity dependency, capital intensity
Fixed Effects Panel Analysis

RCA, The between ECI, Method of human

Reflections capital \& economic development (ED).

There is a strong relationship between EC and ED.

The research states that a RCA, positive

$\begin{array}{llll}\text { (Fortunato } & \text { et } & 97 & \text { 2008- } \\ \text { al., 2015) } & & \text { Countries } & 2012\end{array}$ GDP EXPY, PRODY correlation between EC and ED levels.

Dynamic analyzes are more

RCA, Fixed

(Cristelli et al., All 1995- GDP, the average 2015)

Effects Panel Analysis significant in revealing the relationship between EC and ED. 
International and Multidisciplinary Journal of Social Sciences, 10(2)61

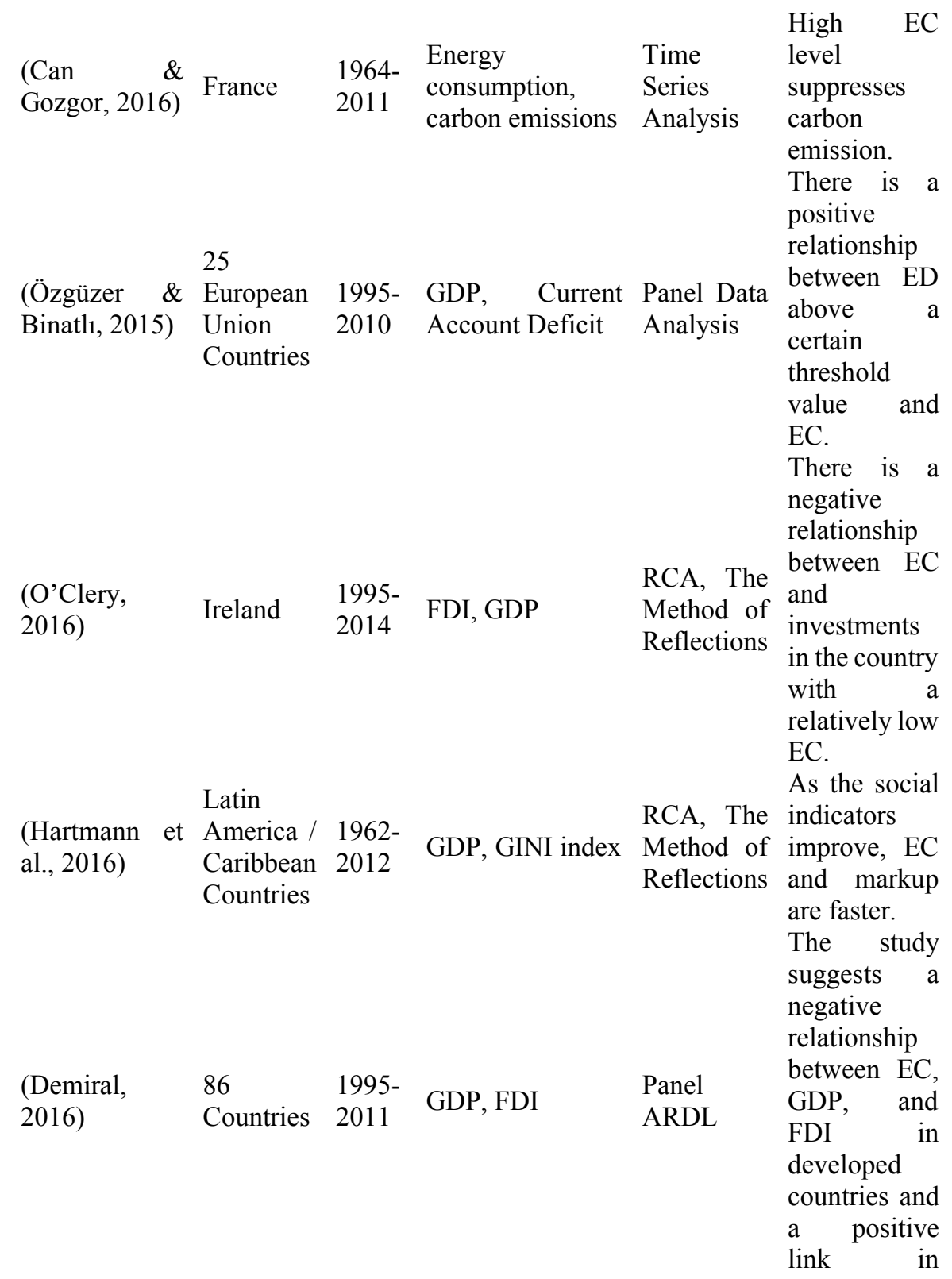


(Hartmann et All al., 2017)
1963- GDP, 2008 Schooling, political stability

(Stojkoski \& South Kocarev, 2017) 2013 GDP, FDI European Countries

(Britto et al., Brazil, 19602017)

$\begin{array}{lll}\text { South } & 1960- & \text { GDP } \\ \text { Korea } & 2000\end{array}$

Latin

Schooling rate,

(Ferraz et al., America 2010- life expectancy, Panel Data 2018) and Asian Countries 2014 the employment Analysis rate

Dynamic

OLS, System

GMM

RCA

developing countries. Investments should be made in R\&D and human capital for more robust \& more complex economies. The research shows a longrun relationship between EC and ED.

Countries with higher levels of EC have higher growth rates.

There is a positive relationship between EC and economic, social indicators. The authors state a relationship (Mealy \& All 1995- CO2 emission, RCA between EC and green goods and renewable energy. 


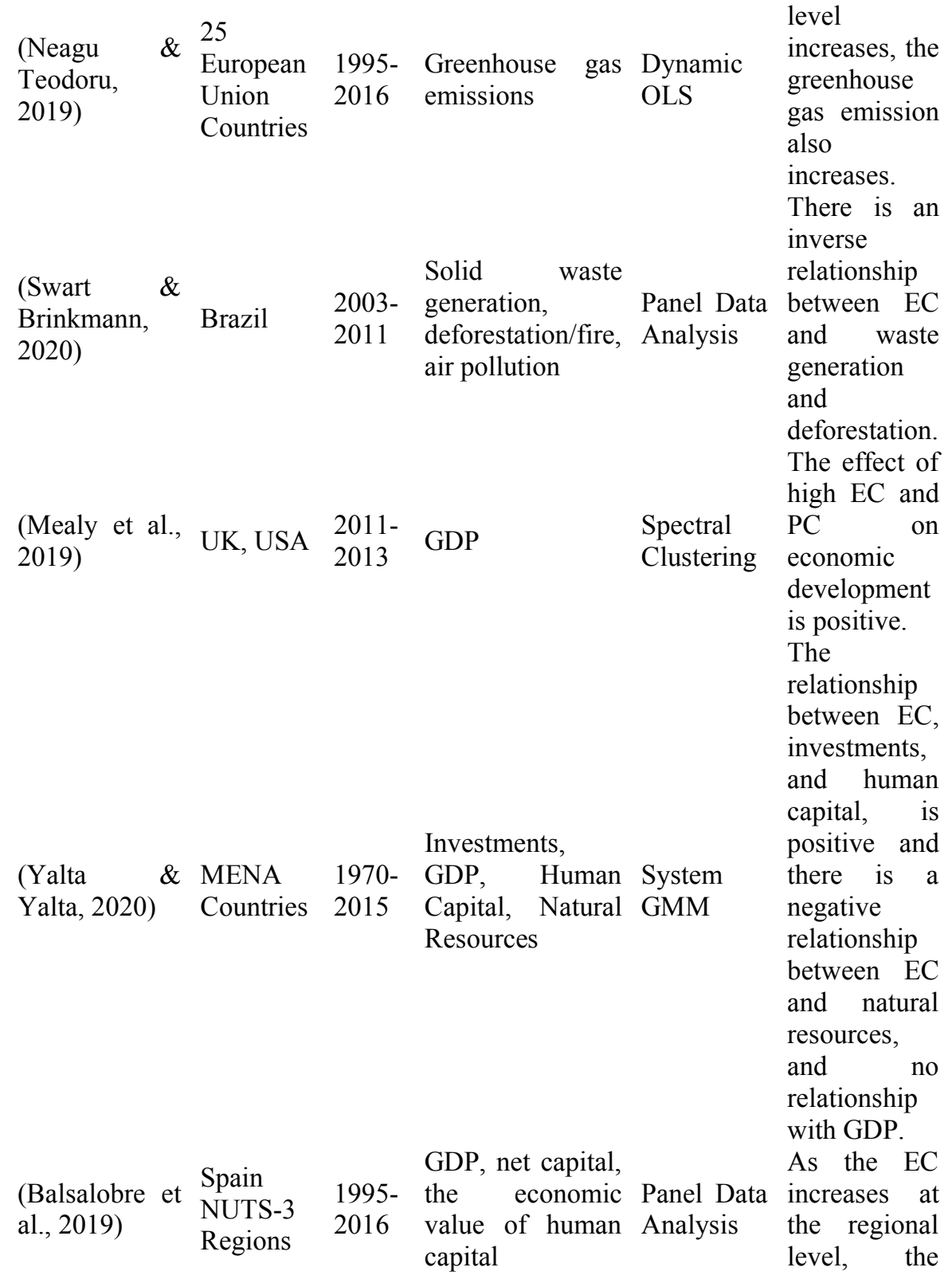


(Romero \&

Gramkow, 2020)

67

Countries

1976-

2012

$\mathrm{CO} 2$ emission

Economic

(Yilanci \&
Pata, 2020)

(Hausmann et al., 2020) relative wage gap decrease.

The increase in $\mathrm{EC}$ decreases carbon emission. The increase in $\mathrm{EC}$ increases the ecological footprint.

The current EC level of an industry provides information about the future of the industry.

According to other applied studies in the literature, this study is different in terms of the data and the System Generalized Moments Method (System GMM) to examine the effects of all accessible indicators of SD on EC.

Table 2.

OECD Member Countries Included in the Analysis

$\begin{array}{cccc}\text { Australia } & \text { France } & \text { Lithuania } & \text { South Korea } \\ \text { Austria } & \text { Germany } & \text { Mexico } & \text { Spain } \\ \text { Belgium } & \text { Greece } & \text { Netherlands } & \text { Sweden } \\ \text { Canada } & \text { Hungary } & \text { New Zealand } & \text { Switzerland } \\ \text { Chile } & \text { Ireland } & \text { Norway } & \text { Turkey } \\ \text { Czech } & \text { Israel } & \text { Poland } & \text { UK } \\ \text { Denmark } & \text { Italy } & \text { Portugal } & \text { USA } \\ \text { Estonia } & \text { Japan } & \text { Slovakia } & \\ \text { Finland } & \text { Latvia } & \text { Slovenia } & \end{array}$

Note: Iceland and Colombia were omitted from the analysis owing to the missing data. The data for Luxembourg was taken with Belgium since its small-scale.

Source: OECD, 2020 
Table 3.

Description of Variables and Sources in Analysis

\begin{tabular}{|c|c|c|c|}
\hline \multicolumn{2}{|l|}{ Variables } & \multirow{2}{*}{$\begin{array}{l}\text { Description } \\
\text { Economic Complexity Index }\end{array}$} & \multirow{2}{*}{$\begin{array}{l}\text { Sources } \\
\text { The Observation of } \\
\text { Economic } \\
\text { Complexity (OEC) }\end{array}$} \\
\hline $\begin{array}{l}\text { Dep. } \\
\text { Variable }\end{array}$ & ECI & & \\
\hline \multirow{6}{*}{ 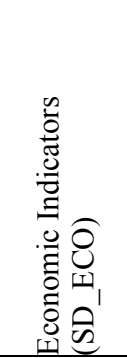 } & LnGDP & GDP Per Capita & World Bank (WB) \\
\hline & UNEMP & Unemployment rate & $\begin{array}{l}\text { International Labor } \\
\text { Organization (ILO) }\end{array}$ \\
\hline & FDI & Net FDI / GDP & WB \\
\hline & CAD & $\begin{array}{l}\text { Current Account Deficit / } \\
\text { GDP }\end{array}$ & WB \\
\hline & RDGDP & R\&D / GDP & WB \\
\hline & LnRRD & $\begin{array}{l}\text { Researchers in R\&D (per } \\
\text { million people) }\end{array}$ & WB \\
\hline \multirow{6}{*}{ 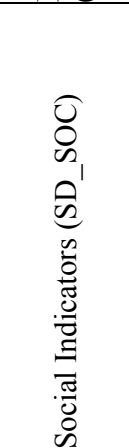 } & GINI & GINI Coefficient & $\begin{array}{lr}\text { Federal } & \text { Reserve } \\
\text { Economic } & \text { Data } \\
\text { (FRED) } & \end{array}$ \\
\hline & WOMEN & $\begin{array}{l}\text { Labor force participation } \\
\text { rate, female }\end{array}$ & ILO \\
\hline & HDI & Human Development Index & $\begin{array}{l}\text { United Nations } \\
\text { Development } \\
\text { Program (UNDP) }\end{array}$ \\
\hline & CRIME & $\begin{array}{l}\text { Homicide rate per } 100,000 \\
\text { people }\end{array}$ & WB \\
\hline & LnFIVE & Under-five Mortality Rate & WB \\
\hline & LnSSPEND & Social Spending & OECD \\
\hline \multirow{6}{*}{ 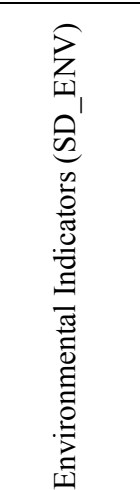 } & WATER & $\begin{array}{l}\text { Percentage of population } \\
\text { using safely managed water } \\
\text { services }\end{array}$ & $\mathrm{UN}$ and $\mathrm{WB}$ \\
\hline & HEALTH & $\begin{array}{l}\text { People who reach safely } \\
\text { managed sanitation services }\end{array}$ & $\mathrm{UN}$ and $\mathrm{WB}$ \\
\hline & TRANSCO2 & $\begin{array}{l}\mathrm{CO}_{2} \text { emissions from } \\
\text { transport }\end{array}$ & WB \\
\hline & MANUCO2 & $\begin{array}{lll}\mathrm{CO}_{2} & \text { emissions } & \text { from } \\
\text { manufacturing } & \end{array}$ & OECD \\
\hline & RENEW & $\begin{array}{l}\text { Renewable } \\
\text { consumption }\end{array}$ & WB \\
\hline & LnGREEN & 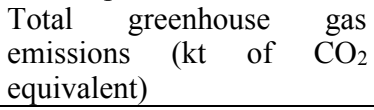 & WB \\
\hline
\end{tabular}

Note: To stabilize the variance of the variables, The log transformation of GDP, RRD, FIVE, SSPEND, and GREEN was employed. 


\section{Effects of SD's Indicators on EC: Panel Data Analysis}

In this study, we investigated the impact of the economic, social, and environmental indicators of SD on EC in OECD member countries in panel data analysis to determine which indicator(s) of the SD affect the EC.

In the study, annual panel data for the period 1996-2017 were used for OECD members whose data is available in estimating the effects of SD's indicators on EC. The panel data's cross-sectional aspect $(\mathrm{N}=34)$ is bigger than the time $(\mathrm{T}=21)$. In the study, global indicators (economic, social, and environmental) of SD were taken into consideration by considering the SD targets of the United Nations (UN) for 2030 (United Nations, 2007, 2015).

The variables in the analysis and the institutions from which the obtained data of variables are summarized in Table 3.

\section{Methodology}

In this study, the impact of SD indicators on EC, which follow a dynamic process due to its nature, are estimated. Dynamic Panel Data (DPD) estimation methods, including the dependent variable's lagged value, were used to estimate these effects. Generalized Moments Method (GMM), a fundamental DPD analysis, is frequently used in the literature. GMM is a method that deals with autocorrelation, endogeneity, and heteroscedasticity problems. It can be divided into traditional and the System GMM (Arellano \& Bond, 1991; Arellano \& Bover, 1995).

In the traditional / difference GMM developed by Arellano and Bond in 1991, variables' lagged values (subtracting the value of the previous period from the variable's value in the current period) are used as Instrumental Variables (IV). IV for equations in the first differences are predetermined. Arellano \& Bond (1991) suggested using all valid lagged variables as an IV in dynamic panel data models (Arellano \& Bond, 1991). Thus, it is accepted that all explanatory variables and individual effects are eventually correlated, and inconsistency of the estimator being founded on deviations of initial observations could be avoided (Arellano \& Bover, 1995). However, the traditional GMM estimator can lead to high bias and low accuracy in applied studies. The main reason for this is that the variables' lagged values provide weak instrumental variables for the first differences (Blundell \& Bond, 1998). 
Arellano and Bover proposed the System GMM estimator in 1995 (Arellano \& Bover, 1995). The System GMM estimator allows the dependent variable' lagged levels to be employed as an IV in first difference equations and enables the lagged differences of the dependent variable as an IV in the level equations. Unlike the first-differenced method, The System GMM estimator takes the differences of an average of available future values of a variable. This estimation method was developed by Blundell and Bond in 1998 and proved to be better than the first-differenced GMM estimator. Accordingly, biases that occur in the use of IV variables are eliminated, and the coefficients become more sound (Blundell \& Bond, 1998; Bond, 2002). Therefore, the System GMM estimator gives robust prediction results.

The System GMM was used in this study since it is suitable in the case of $\mathrm{N}>\mathrm{T}$, and dependent variables are affected by their own lagged values. Besides, whether there would be a correlation between independent variables, endogeneity problem between independent variables and error terms, and bias caused by the individual effect, etc., The System GMM can deal with these problems (Roodman, 2009b; Stock \& Watson, 2006). The base function used in the study is as follows.

$$
\begin{aligned}
& E C I_{i, t}=f\left(E I_{i, t-1}, \text { SDVariables }_{i, t}\right. \\
& \quad i=1,2, \ldots, N, \text { and } t \\
& \quad i=1,2, \ldots, T)
\end{aligned}
$$

where $\mathrm{ECI}_{\mathrm{i}, \mathrm{t}}$ shows the Economic complexity index of country $i$ in time $t$, as a dynamic independent variable $\mathrm{ECI}_{\mathrm{i}, \mathrm{t-1}}$ represents one period lagged value of ECI, and lastly, SDVariables $\mathrm{it}_{\mathrm{t}}$ (SD_ECO, SD_SOC, and SD_ENV) shows represent independent variables and the subscripts $i$ and $t$ index countries and time respectively.

Based on Eq.(1) for predicting the effects of SD on EC, a dynamic panel data equation was created, as indicated below.

$$
E C I_{i, t}=\beta_{0}+\beta_{1} E C I_{i, t-1}+\beta_{\tau} \text { SDVariables }_{i, t}+\beta_{3} Z_{i, t}+\mu_{i}+\varepsilon_{i, t}
$$

where ECI is Economic Complexity Index; SDVariables (SD_ECO, SD_SOC, and SD_ENV) are independent variables, $\mathrm{Z}$ is a control variable. In addition, the model contains unobservable individual effect $\mu$, and an error 
term $\varepsilon$ when $\mu_{i}=\left(0, \sigma_{\mu}^{2}\right), \varepsilon_{i, t}=\left(0, \sigma_{\varepsilon}^{2}\right) . \beta_{0}$ is a constant term, and $\beta_{1}, \beta_{\tau}$ and $\beta_{3}$ are estimation coefficients.

To eliminate the individual-specific (unobservable) effect, it was taken first differences of Eq.(2), and it can be rewritten as Eq.(3).

$$
\Delta E C I_{i, t}=\beta_{0}+\beta_{1} \Delta E C I_{i, t-1}+\beta_{\tau} \Delta S \text { VVariables }_{i, t}+\beta_{3} \Delta Z_{i, t}+\Delta \varepsilon_{i, t}
$$

where $\Delta \mathrm{ECI}_{\mathrm{i}, \mathrm{t}}=\left(\mathrm{ECI}_{\mathrm{i}, \mathrm{t}}-\mathrm{ECI}_{\mathrm{i}, \mathrm{t}-1}\right), \Delta \mathrm{ECI}_{\mathrm{i}, \mathrm{t}-1}=\left(\mathrm{ECI}_{\mathrm{i}, \mathrm{t}-1}-\mathrm{ECI}_{\mathrm{i}, \mathrm{t}-2}\right)$, $\Delta$ SDVariables $_{i, t}=\left(\right.$ SDVariables $_{i, t}-$ SDVariables $\left._{i, t-1}\right), \Delta Z_{i, t}=\left(Z_{i, t}-Z_{i, t-1}\right)$ and $u_{i, t}$ $=\left(\mu_{\mathrm{i}}+\varepsilon_{\mathrm{i}, \mathrm{t}}\right)$ becomes $\Delta \mathrm{u}_{\mathrm{i}, \mathrm{t}}=\mathrm{u}_{\mathrm{i}, \mathrm{t}}-\mathrm{u}_{\mathrm{i}, \mathrm{t}-1}=\left(\mu_{\mathrm{i}}+\varepsilon_{\mathrm{i}, \mathrm{t}}\right)-\left(\mu_{\mathrm{i}}+\varepsilon_{\mathrm{i}, \mathrm{t}-1}\right)=\Delta \varepsilon_{\mathrm{i}, \mathrm{t}}$. Afterwards, separate equations were created based on Eq.(3) which is a difference GMM. For the variables in the level lagged variables are used and then the System GMM regression equations were obtained.

$$
\begin{aligned}
& E\left(E C I_{i, t-1}-E C I_{i, t-2}\right)\left(\mu_{i}+\varepsilon_{i, t}\right)=0, \\
& E\left(S D_{-} E C O_{i, t-1}-S D_{-} E C O_{i, t-2}\right)\left(\mu_{i}+\varepsilon_{i, t}\right)=0, \\
& E\left(S D_{-} S O C_{i, t-1}-S D_{-} S O C_{i, t-2}\right)\left(\mu_{i}+\varepsilon_{i, t}\right)=0, \\
& E\left(S D_{-} E N V_{i, t-1}-S D_{-} E N V_{i, t-2}\right)\left(\mu_{i}+\varepsilon_{i, t}\right)=0, \\
& E\left(Z_{i, t-1}-Z_{i, t-2}\right)\left(\mu_{i}+\varepsilon_{i, t}\right)=0
\end{aligned}
$$

and under these moment conditions, the equations employed for predictions as follows;

$$
\begin{aligned}
& E C I_{i, t}=\beta_{0}+\beta_{1} E C I_{i, t-1}+\beta_{\tau} S D_{-} E C O_{i, t}+\beta_{3} Z_{i, t}+\varepsilon_{i, t} \\
& E C I_{i, t}=\beta_{0}+\beta_{1} E C I_{i, t-1}+\beta_{\tau} S D_{-} S O C_{i, t}+\beta_{3} Z_{i, t}+\varepsilon_{i, t} \\
& E C I_{i, t}=\beta_{0}+\beta_{1} E C I_{i, t-1}+\beta_{\tau} S D_{-} E N V_{i, t}+\beta_{3} Z_{i, t}+\varepsilon_{i, t}
\end{aligned}
$$

While estimating from Eq.(4) to Eq.(6), sub-indicators for each base SD indicator (ECO, SOC, and ENV) are included in the equations. In the study, AR(1), AR(2), Sargan, and Hansen tests were conducted to determine whether the System GMM estimators are consistent and robust, and the selected IVs were tested.

The IV's validity and the no autocorrelation problems between error terms indicate that consistent and effective estimates can be made with the GMM estimator. With Sargan and Hansen tests that fit the $\chi^{2}$ distribution asymptotically, null hypotheses such as "IV are relevance" are tested. The Sargan test, which is not affected by too many IVs, is not robust due to the 
assumption of errors being homoscedastic. The Hansen Test, on the other hand, is robust due to the heteroskedasticity assumption; however, as the number of instrument variables increases, the effectiveness of the test weakens (Roodman, 2009a, 2009b). The relevance of IV determination is tested by investigating the presence of autocorrelation with Arellano-Bond's AR (1) and AR (2) tests. The null hypothesis of autocorrelation tests states that "there is no first-order autocorrelation" in $\mathrm{AR}(1)$ and "there is no secondorder autocorrelation" in AR(2). The method for determining IVs leads to the first-order autocorrelation between error terms. Therefore, rejecting $\mathrm{H}_{0}$ in the $\mathrm{AR}(1)$ test and accepting $\mathrm{H}_{0}$ in the $\mathrm{AR}(2)$ indicates that the instrument variables were selected correctly (Arellano \& Bond, 1991; Arellano \& Bover, 1995). The study also investigated whether the coefficient of each independent variable in the equations is statistically significant as a whole by performing the Wald $\left(\chi^{2}\right)$ test (Roodman, 2009a).

Since the estimation of the independent variables in the System GMM is considered exogenous and $\mu_{\mathrm{i}}=\left(0, \sigma_{\mu}^{2}\right), \varepsilon_{\mathrm{i}, \mathrm{t}}=\left(0, \sigma_{\varepsilon}^{2}\right)$, hence whether the data belonging to the variables are stationary or not does not affect the equation estimates; therefore, variables are considered to be stationary (Jung et al., 2015).

In the study, before the equation estimation, it was first investigated whether there is a correlation between the units to test the mentioned acceptance validity. In order to avoid false regression results in the analysis, the stationarities of the data of the variables are investigated by first and second-generation unit root tests. The assumption of "there is no crosssectional dependency" in the 1st generation tests is the main difference between them. For this reason, the $\mathrm{H}_{0}$ of "No cross-sectional dependency" was tested with Breusch-Pagan (LM), Pesaran (LM), and Friedman (CD) tests. Thus, the CADF-CIPS test, the second-generation unit root test that considers the cross-sectional dependency and conforms to the $\mathrm{N}>\mathrm{T}$ condition, was performed. In the CADF Test, which is the expanded form of the standard ADF unit root test, the $\mathrm{H}_{0}$ hypothesis is "Series are not stationary". In addition, with the CADF test, the stability test is performed for each country that forms the panel, and test statistics are calculated. Stationarity analysis is performed for the entire panel with the CIPS Z (t-bar) statistics calculated by taking the arithmetic mean of individual CADF tests (Baltagi \& Pesaran, 2007; Pesaran, 2007). 


\section{Yaprakli \& Özden - The Effect of Sustainable Development}

For panel data analysis, STATA 15.0 software program and E-Views 10.0 econometric package program were used. The module (xtabond2) developed by Roodman was used to estimate the System GMM (Roodman, 2009b).

\section{Results}

Cross-sectional dependency for variables from Eq.(4) to Eq.(6) among the units that make up the panel (34 OECD member countries) was inspected with Breusch-Pagan (LM), Pesaran (LM), and Friedman (CD) tests.

Table 4.

Test Results for Cross Section Dependence

\begin{tabular}{lcc} 
Tests & Test Statistics & p-Value \\
\hline Breusch-Pagan & 4216,160 & 0,000 \\
Pesaran & 11,023 & 0,000 \\
Friedman & 69,342 & 0,0002
\end{tabular}

Table 4 shows that as a result of the tests that examine cross-sectional dependency, $\mathrm{H}_{0}$ is rejected at the $1 \%$ significance level. Accordingly, it points out that a shock that might occur in any country in a panel may impact other countries to different degrees. In this case, the panel data's stationarities were investigated by the Pesaran CADF-CIPS, the second-generation unit root tests (Baltagi, 2012). The AIC criterion was used to decide the appropriate lag length. The CADF-CIPS test results are presented in Table 5.

In Table 5, CIPS Z (t-bar) test statistics show that variables used in the study are stationary in level values [I(0)]; in short, they do not contain unit roots. These findings indicate that Jung's assumption that the System-GMM estimation data are stationary is relevant (Jung et al., 2015).

The System GMM panel data regression analysis was applied for equations from Eq.(4) to Eq.(6) to determine the effects of economic, social, and environmental indicators of SD on ECI. Table 6 gives the results of the models estimated by the System GMM. 
International and Multidisciplinary Journal of Social Sciences, 10(2)71

Table 5.

CADF and CIPS Unit Root Test Results

\begin{tabular}{|c|c|c|c|}
\hline Variables & $\begin{array}{l}\text { Constant and } \\
\text { Trend } \\
\text { Z(t-bar) Test }\end{array}$ & Lags & $\mathrm{p}$-value \\
\hline ECI & $-1,752^{(\mathrm{b})}$ & 0 & 0,039 \\
\hline LnGDP & $-3,080^{(a)}$ & 0 & 0,001 \\
\hline UNEMP & $-3,841^{(a)}$ & 0 & 0,000 \\
\hline FDI & $-2,221^{(b)}$ & 0 & 0,004 \\
\hline CAD & $-2,741^{(b)}$ & 0 & 0,003 \\
\hline RDGDP & $-1,662^{(b)}$ & 0 & 0,048 \\
\hline LnRRD & $-1,766^{(\mathrm{c})}$ & 0 & 0,009 \\
\hline GINI & $-1,829^{(c)}$ & 0 & 0,008 \\
\hline WOMEN & $-1,978^{(\mathrm{c})}$ & 0 & 0,007 \\
\hline HDI & $-3,965^{(a)}$ & 0 & 0,000 \\
\hline CRIME & $-1,969^{(\mathrm{c})}$ & 0 & 0,008 \\
\hline LnFIVE & $-3,026^{(a)}$ & 0 & 0,000 \\
\hline LnSSPEND & $-1,755^{(\mathrm{c})}$ & 0 & 0,010 \\
\hline WATER & $-2,366^{(\mathrm{c})}$ & 0 & 0,006 \\
\hline HEALTH & $-2,326^{(b)}$ & 0 & 0,005 \\
\hline TRANSCO2 & $-1,700^{(\mathrm{c})}$ & 0 & 0,010 \\
\hline MANUCO2 & $-2,781^{(b)}$ & 0 & 0,003 \\
\hline RENEW & $-2,395^{(b)}$ & 0 & 0,003 \\
\hline LnGREEN & $-1,832^{(\mathrm{c})}$ & 0 & 0,008 \\
\hline
\end{tabular}

$\mathrm{a}, \mathrm{b}$ and $\mathrm{c}$ demonstrate statistical significance at the $1 \%, 5 \%$, and $10 \%$ level of significance. Critical values for CIPS test statistics are taken from Table II (c) in Pesaran's (2007) study.

According to the statistical test results in Table 6, $\operatorname{AR}(1)$ and $\operatorname{AR}(2)$ statistical values of the equations show the first-order autocorrelation, but there is no second-order autocorrelation. Sargan and Hansen Tests, which test the relevance of IV in the equations and overidentifying restrictions, were applied, and the null hypothesis is accepted. Wald $\lambda^{2}$ values, which test the significance of each equation separately as a whole, were found to be 
significant at a 1\% significance level for Eq.(4), Eq.(5), and Eq.(6). Based on the test results, the System GMM estimators are consistent.

Table 6.

System GMM Regression Results

Eq. (4)

Eq. (5)

Eq. (6)

\begin{tabular}{|c|c|c|c|c|c|c|}
\hline Variables & Coefficient & $\begin{array}{l}\text { Robust } \\
\text { Std.Error }\end{array}$ & Coefficient & $\begin{array}{l}\text { Robust Std. } \\
\text { Error }\end{array}$ & Coefficient & $\begin{array}{l}\text { Robust Std. } \\
\text { Error }\end{array}$ \\
\hline L.ECI & $0.682^{\text {(a) }}$ & 0.171 & $0.569^{(\mathrm{a})}$ & 0.429 & $0.484^{(a)}$ & 0.117 \\
\hline LnGDP & $0.136^{(\mathrm{b})}$ & 0.068 & & & & \\
\hline UNEMP & -0.326 & 0.414 & & & & \\
\hline FDI & $0.118^{(a)}$ & 0.034 & & & & \\
\hline CAD & -0.053 & 0.187 & & & & \\
\hline RDGDP & $0.438^{(a)}$ & 0.121 & & & & \\
\hline LnRRD & -0.353 & 0.186 & & & & \\
\hline GINI & & & $0.151^{(\mathrm{b})}$ & 0.071 & & \\
\hline WOMEN & & & 0.094 & 0.105 & & \\
\hline HDI & & & $0.123^{(a)}$ & 0.030 & & \\
\hline CRIME & & & -0.030 & 0.102 & & \\
\hline LnFIVE & & & 0.067 & 0.059 & & \\
\hline LnSSPEND & & & -0.024 & 0.020 & & \\
\hline WATER & & & & & -0.233 & 0.309 \\
\hline HEALTH & & & & & 0.453 & 0.329 \\
\hline TRANSCO2 & & & & & 0.061 & 0.110 \\
\hline MANUCO2 & & & & & $-0.339^{(a)}$ & 0.085 \\
\hline RENEW & & & & & $0.225^{(\mathrm{b})}$ & 0.110 \\
\hline LnGREEN & & & & & $-0.085^{(\mathrm{b})}$ & 0.040 \\
\hline \multicolumn{7}{|c|}{ Statistical Tests } \\
\hline Tests & Test Stat. & $\mathrm{p}$-value & Test Stat. & $\mathrm{p}$-value & Test Stat. & p-value \\
\hline $\mathrm{AR}(1)$ & $-3,95$ & 0,000 & $-4,22$ & 0,000 & $-4,05$ & 0,000 \\
\hline $\mathrm{AR}(2)$ & $-1,55$ & 0,121 & $-1,54$ & 0,124 & $-1,51$ & 0,131 \\
\hline Sargan Test & 25,77 & 0,524 & 35,18 & 0,698 & 22,91 & 0,480 \\
\hline Hansen Test & 11,44 & 0,324 & 18,35 & 0,457 & 11,76 & 0,332 \\
\hline Wald $\lambda^{2}$ & 14099,99 & 0,000 & 27716,27 & 0,000 & 15419,93 & 0,000 \\
\hline
\end{tabular}

a, $b$ and c show statistical significance at the $1 \%, 5 \%$, and $10 \%$ level of significance. 
The estimation results denote that the lagged dependent variable (ECI) coefficients in all the models are statistically significant. The lagged value of ECI affects itself positively at $0.68,0.57$, and 0.48 , respectively. According to Eq.(4), GDP, FDI, and RDGDP variables, which are among the economic indicators of SD, affect EC positively and statistically significant at $0.14,0.12$, and 0.44 , respectively. It shows that GINI and HDI, which are among the social indicators of SD, positively ( 0.15 and 0.12 , respectively) and statistically significantly affect EC. While the effects of MANUCO2 and LnGREEN indicators of SD on EC are adverse at the level of 0.34 and 0.09, respectively, the impact of RENEW is positive (0.23).

The estimation results in Table 6 point out the increase in EC level in OECD countries enables the quality of commercial goods to increase and the production of more complex goods. The results stated that the rise in national income, foreign direct investment, and the share of GDP allocated to R\&D would contribute to the increase of the EC level. In the context of high human capital levels and the elimination of unfair distribution of income, it can be stated that social progress may lead to an increase in EC levels. Finally, it is possible to say that the improvement in environmental indicators such as $\mathrm{CO}_{2}$ emission resulting from production, greenhouse gas emission, and renewable energy consumption will contribute to the increase of EC.

The analysis results indicate that it is necessary to increase the public support for R\&D expenditures and physical capital investments and increase the activities to be carried out through the public / private sector to make the net effects of the SD on EC positive. Besides, the increase in the human capital index, which includes education, health, and the improvement in income distribution, will increase both other indicators of SD and its effect on EC. Using renewable energy sources instead of fossil energy sources that damage the environment is essential in the transition to a sustainable green economy and gaining a competitive advantage in high commodity trade that will increase the EC level.

\section{Conclusion}

The effects of sustainable development indicators on economic complexity were analyzed with the System GMM, one of the dynamic panel data methods, using panel data for OECD countries for 1996-2017 in the study. 


\section{Yaprakli \& Özden - The Effect of Sustainable Development}

According to the statistical test results of the analyses, $\mathrm{AR}(1)$ and $\mathrm{AR}(2)$ statistical values of the equations indicate a first-order autocorrelation and no second-order autocorrelation. Sargan and Hansen tests show that the instrument variables in the equations are relevant, and Wald $\lambda^{2}$ indicates that all the estimated equations are significant as a whole. Based on these findings, the System GMM estimators applied in the study are consistent.

According to the analysis findings, the first lag of the EC affects the current value of the EC positively and significantly. The effects of GDP per capita, FDI, and R\&D / GDP, which are economic indicators of SD, on EC are positive and statistically significant. Also, the GINI coefficient and human capital index, which are among the social indicators of SD, positively and statistically significantly affect the EC. While the effects of SD's environmental indicators such as $\mathrm{CO}_{2}$ emissions from manufacturing and total greenhouse gas emissions are adverse effects on EC, renewable energy consumption is positive on EC.

Based on the analysis results, it is possible to state that SD's indicators have different degrees of influence on EC in OECD countries that also have Turkey as a member. There is a need for political stances and objective targets to maximize SD's positive effect on EC. In this context, it is necessary to switch to technology and knowledge-based production process, expand to qualified production factor capacity, raise social living standards, make investments towards a green economy and stabilize sustainability.

\section{Acknowledgments}

This paper was organized from the doctoral dissertation, namely "The Effects of The Determinants of Sustainable Development on Economic Complexity: An Econometric Analysis on OECD Countries and A Decision-Making Analysis on Turkey”.

\section{Declaration of Conflicting Interest}

The authors declare that there is no conflict of interest.

\section{References}

Arellano, M., \& Bond, S. (1991). Some tests of specification for panel data Monte-Carlo evidence and an application to employment equations. 
Review of Economic Studies, 58(2), 277-297.

https://doi.org/10.2307/2297968

Arellano, M., \& Bover, O. (1995). Another look at the instrumental variable estimation of error-components models. Journal of Econometrics, 68(1), 29-51. https://doi.org/10.1016/0304-4076(94)01642-D

Balsalobre, P., José, S., Verduras, C. L., \& Lanchas, J. D. (2019). Measuring the economic complexity at the sub-national level using international and interregional trade.

https://ideas.repec.org/p/ipt/termod/201905.html

Baltagi, B. H. (2012). Econometric Analysis of Panel Data (4th ed.). Wiley. Baltagi, B. H., \& Pesaran, M. H. (2007). Heterogeneity and Cross Section Dependence in Panel Data Models: Theory and Applications: Introduction. Journal of Applied Econometrics, 22(2), 229-232. https://doi.org/10.1002/jae.955

Bastos, F. R., \& Wang, K. (2015). Long-Run Growth in Latin America and the Caribbean: The Role of Economic Diversification and Complexity. Regional Economic Outlook, 67-77. https://tinyurl.com/65ekfmfa Blundell, R., \& Bond, S. (1998). Initial conditions and moment restrictions in dynamic panel data models. Journal of Econometrics, 87(1), 115-143. https://doi.org/10.1016/S0304-4076(98)00009-8

Bond, S. (2002). Dynamic panel data models: a guide to micro data methods and practice. Portuguese Economic Journal, 1, 141-162. https://doi.org/10.1007/s10258-002-0009-9

Britto, G., Romero, J., Freitas, E. E., \& Coelho, C. (2017). the Great Divide: Economic Complexity and Development Paths in Brazil and South Korea. 1404-1425. https://doi.org/10.5151/engpro-1enei-078

Can, M., \& Gozgor, G. (2016). Dynamic Relationships among CO2 Emissions, Energy Consumption, Economic Growth, and Economic Complexity in France (Issue 70373). https://ideas.repec.org/p/pra/mprapa/70373.html

Cosbey, A. (1996). Trade and sustainable development: The global picture. International Institute for Sustainable Development.

https://www.iisd.org/system/files/publications/trade_and_sd.pdf Cristelli, M., Tacchella, A., \& Pietronero, L. (2015). The Heterogeneous Dynamics of Economic Complexity. PLoS ONE, 10(2), e0117174. https://doi.org/10.1371/journal.pone.0117174 
76 Yaprakli \& Özden - The Effect of Sustainable Development

Demiral, M. (2016). Knowledge, Complexity and Economic Growth: Multicountry Evidence by Development Stages. Journal of Knowledge Management, Economics and Information Technology, VI(1), 1-27. https://tinyurl.com/75udr66u

Felipe, J., Kumar, U., Abdon, A., \& Bacate, M. (2012). Product complexity and economic development. Structural Change and Economic Dynamics, 23(1), 36-68. https://doi.org/10.1016/j.strueco.2011.08.003 Ferrarini, B., \& Scaramozzino, P. (2013). Complexity, Specialization, and Growth (ADB Economics Working Paper Series, Issue 334). https://www.adb.org/sites/default/files/publication/30213/economicswp-344-complexity-specialization-growth.pdf

Ferraz, D., Janaina, N., Silveira, C., Moralles, H. F., Aparecida, D., Nascimento, D. O., \& Pyka, A. (2017). An Efficiency Analysis of Economic Complexity and Human Development in 2013. http://rmeconference.com/submission/proceedings/files/159.pdf Fortunato, P., Razo, C., \& Vrolijk, K. (2015). Operationalizing the product space: A road map to export diversification. United Nations Conference on Trade and Development, No. 219. https://econpapers.repec.org/RePEc:unc:dispap:219

Hartmann, D. (2014). Economic complexity and human development: How economic diversification and social networks affect human agency and welfare (1st ed.). Routledge. https://doi.org/10.4324/9780203722084 Hartmann, D., Guevara, M. R., Jara-Figueroa, C., Aristarán, M., \& Hidalgo, C. A. (2017). Linking Economic Complexity, Institutions, and Income Inequality. World Development, 93, 75-93. https://doi.org/10.1016/j.worlddev.2016.12.020

Hartmann, D., Jara-Figueroa, C., Guevara, M., Simoes, A., \& Hidalgo, C. A. (2016). The structural constraints of income inequality in Latin America. Integration \& Trade Journal, 40, 70-85. https://arxiv.org/abs/1701.03770

Hausmann, R., Hidalgo, C. A., Stock, D. P., \& Yildirim, M. A. (2020). Implied Comparative Advantage.

https://www.hks.harvard.edu/centers/cid/publications/faculty-workingpapers/implied-comparative-advantage

Hausmann, R., Hwang, J., \& Rodrik, D. (2006). What You Export Matters (Issue 11905). https://doi.org/10.3386/w11905 
Hausmann, R., \& Klinger, B. (2007). The Structure of the Product Space and the Evolution of Comparative Advantage. In CID working paper,

Harvard University, Cambridge (Issue No. 146).

https://doi.org/10.1111/j.1475-4932.1987.tb00650.x

Hidalgo, C. A. (2009). The Dynamics of Economic Complexity and the

Product Space over a 42 year period.

https:/www.hks.harvard.edu/centers/cid/publications/faculty-workingpapers/dynamics-economic-complexity-and-product-space-over-42year-period

Hidalgo, C. A., \& Hausmann, R. (2009). The building blocks of economic complexity. Proceedings of the National Academy of Sciences, 106(26), 10570-10575. https://doi.org/10.1073/pnas.0900943106

Jarreau, J., \& Poncet, S. (2012). Export sophistication and economic growth:

Evidence from China. Journal of Development Economics, 97(2), 281292. https://doi.org/10.1016/j.jdeveco.2011.04.001

Jung, H., Kwon, H. U., \& Jeon, G. (2015). An Alternative System GMM

Estimation inDynamic Panel Models. Journal of Economic Theory and Econometrics, 26(2), 57-78. http://es.re.kr/eng/upload/jetem-26-2-

3.pdf

Mealy, P., Farmer, J. D., \& Teytelboym, A. (2019). Interpreting Economic

Complexity. https://doi.org/10.1126/sciadv.aau1705

Mealy, P., \& Teytelboym, A. (2018). Economic Complexity and the Green

Economy. SSRN Electronic Journal.

https://doi.org/10.2139/ssrn.3111644

Munasinghe, M. (2001). Sustainable development and climate change:

applying the sustainomics transdisciplinary meta-framework.

International Journal of Global Environmental Issues, 1(1), 13-55.

https://doi.org/10.1504/ijgenvi.2001.000970

Munasinghe, M. (2009). Sustainable Development in Practice: Sustainomics

Methodology and Applications. In Sustainable Development in

Practice: Sustainomics Methodology and Applications (Issue June

2009). Cambridge University Press.

https://doi.org/10.1017/CBO9780511626777

Neagu, O., \& Teodoru, M. C. (2019). The relationship between economic complexity, energy consumption structure and greenhouse gas emission: Heterogeneous panel evidence from the EU countries. 
78 Yaprakli \& Özden - The Effect of Sustainable Development

Sustainability (Switzerland), 11(2). https://doi.org/10.3390/su11020497 O'Clery, N. (2016). A tale of two clusters: The evolution of Ireland's economic complexity since 1995. Journal of the Statistical and Social Inquiry Society of Ireland, 45(317), 482-487.

https://growthlab.cid.harvard.edu/publications/tale-two-clustersevolution-ireland's-economic-complexity-1995

OECD. (2020). International Trade by Commodity Statistics Volume 2020 Issue 1. https://doi.org/10.1787/162308f8-en

Ourens, G. (2017). Economic Complexity and Growth (Vol. 32, Issue 0). http://www.springer.com/series/11583

Özgüzer, G. E., \& Binatl1, A. O. (2016). Economic Convergence in the EU: A Complexity Approach. Eastern European Economics, 54(2), 93-108. https://doi.org/10.1080/00128775.2015.1126787

Pesaran, M. (2007). A simple panel unit root test in the presence of crosssection dependence. Journal of Applied Econometrics, 22(2), 265-312. https://doi.org/https://doi.org/10.1002/jae.951

Poncet, S., \& de Waldemar, F. (2013). Export Upgrading and Growth: The Prerequisite of Domestic Embeddedness. World Development, 51(C), 104-118. https://doi.org/10.1016/j.worlddev.2013.05.010

Rodrik, D. (2006). What's so special about China's exports. China and World Economy, 14(5), 1-19. https://doi.org/10.1111/j.1749124X.2006.00038.X

Romero, J. P., \& Gramkow, C. (2020). Economic Complexity and Greenhouse Gas Emission Intensity. https://doi.org/10.13140/RG.2.2.30475.11041

Roodman, D. (2009a). A note on the theme of too many instruments. Oxford Bulletin of Economics and Statistics, 71(1), 135-158.

https://doi.org/10.1111/j.1468-0084.2008.00542.x

Roodman, D. (2009b). How to do xtabond2: An introduction to difference and system GMM in Stata. Stata Journal, 9(1), 86-136. https://doi.org/10.1177/1536867x0900900106

Simoes, A., \& Hidalgo, C. A. (2011). The Economic Complexity

Observatory: An Analytical Tool for Understanding the Dynamics of Economic Development. Association for the Advancement of Artificial Intelligence. https://tinyurl.com/emw2smkn

Spatafora, M. N., Anand, R., \& Mishra, M. S. (2012). Structural 
transformation and the sophistication of production. In International Monetary Fund (Vol. 12, Issue 59).

https://doi.org/10.5089/9781463937775.001.

Stock, J. H., \& Watson, M. W. (2006). Introduction to Econometrics (2nd ed.). Addison-Wesley Series in Economics.

Stojkoski, V., \& Kocarev, L. (2017). The Relationship Between Growth and Economic Complexity: Evidence from Southeastern and Central Europe. Munich Personal RePEc Archive, 77837, 0-33. https://doi.org/10.13140/RG.2.2.22873.93282

Swart, J., \& Brinkmann, L. (2019). Economic Complexity and the Environment: Evidence from Brazil. In Universities and Sustainable Communities: Meeting the Goals of the Agenda 2030 (pp. 3-45). Springer, Cham. https://doi.org/10.1007/978-3-030-30306-8_1 United Nations. (2007). Indicators of Sustainable Development: Guidelines and Methodologies. In New York (Issue October).

https://sustainabledevelopment.un.org/index.php?page=view\&type $=40$ $0 \& n r=107 \&$ menu $=1515$

United Nations. (2015). Transforming Your World: The 2030 Agenda for Sustainable Development.

https://sustainabledevelopment.un.org/post2015/transformingourworld/ publication

WCED. (1987). Our common future. 14.

https://sustainabledevelopment.un.org/content/documents/5987ourcommon-future.pdf

Worldbank. (2020). World Bank country and lending groups-country classification. http://www.data.worldbank.org/about/countryclassifications

Yalta, A. Y., \& Yalta, T. (2021). Determinants of Economic Complexity in MENA Countries. Journal of Emerging Economies and Policy, 6(1), 5-16. https://dergipark.org.tr/tr/pub/joeep/issue/60112/825017 Yilanci, V., \& Pata, U. K. (2020). Investigating the EKC hypothesis for China: the role of economic complexity on ecological footprint. Environmental Science and Pollution Research, 27(26), 32683-32694. https://doi.org/10.1007/s11356-020-09434-4 
80 Yaprakli \& Özden - The Effect of Sustainable Development

Sevda Yaprakli is a Professor at the Department of Economics at Ataturk University, Turkey.

Erdemalp Özden is a Research Assistant (Ph.D.) at the Department of Economics at Bayburt University, Turkey.

Email: eozden@bayburt.edu.tr 